Research Report No. 48/2009

\title{
Non-Tradable Share Reform in China: Marching Towards the Berle and Means Corporation?
}

Horace W. H. Yeung

Follow this and additional works at: http:/ / digitalcommons.osgoode.yorku.ca/clpe

\section{Recommended Citation}

Yeung, Horace W. H., "Non-Tradable Share Reform in China: Marching Towards the Berle and Means Corporation?" (2009).

Comparative Research in Law \& Political Economy. Research Paper No. 48/2009.

http://digitalcommons.osgoode.yorku.ca/clpe/156 


\section{Comparative Research in Law \& Political Economy}

Wai Ho Yenug

Non-Tradable Share Reform in China: Marching Towards the Berle and Means Corporation?

EDITORS: Peer Zumbansen (Osgoode Hall Law School, Toronto, Director, Comparative Research in Law and Political Economy, York University), John W. Cioffi (University of California at Riverside), Nassim Nasser (Osgoode Hall Law School, Toronto, Production Editor) 

CLPE Research Paper 48/2009

Vol. 05 No. 09 (2009)

\title{
Wai Ho Yeung
}

\section{Non-Tradable Share Reform in China: Marching ToWards The Berle AND MeAns Corporation?}

\begin{abstract}
In the late 1970s, China initiated gaige kaifang, the twin strategies of reform and opening-up the economy. In the following three decades, the Chinese leaders have been very cautious during China's transition from a planned economy to a market economy. In every reform move, reformers have arguably taken a "one big leap forward but one step backward" approach. State-owned enterprises were successfully transformed into joint stock companies and two stock exchanges were established in the early 1990s. At the same time, a split share structure was created. The majority of shares have been non-tradable. In 2005, to address the problems caused by non-tradable shares, a reform was introduced to unwind these shares. However, at the same time, the government expressly said that "making all shares tradable does not mean selling out all shares". The reform became merely a technical change. Apart from the state's reluctance, the rise of dispersed ownership in China is now a possibility, rather than legally impossible. In the aftermath of the credit crisis, is moving along the Anglo-American path making any sense? Or should China remain where it is? In summary, this paper intends to provide readers with an overview of the past, present and future of the ownership structure problem in China.
\end{abstract}

Key words: China, socialist state ownership, corporate governance, split share structure, nontradable shares.

JEL Classification: K22, N25, 016, P37

Wai Ho Yeung

DPhil Candidate, Faculty of law

Mansfield College, University of Oxford

Email: wai.yeung@law.ox.ac.uk 


\section{NON-TRADABLE SHARE REFORM IN CHINA: MARCHING TOWARDS THE BERLE AND MEANS CORPORATION? \\ Wai Ho Yeung ${ }^{*}$}

\section{INTRODUCTION}

"Securities, stock markets, are they good or evil? Are they dangerous or safe? Are they unique to capitalism or also applicable to socialism? Let's try and see." - Deng Xiaoping ${ }^{1}$ In 1978, the Central Government commenced a long-term economic development program to revitalize the national economy. State-owned enterprises (SOEs) were restructured into joint stock companies. Funds would no longer be centrally administered and allocated to these SOEs. They needed to diversify their fund-raising channels, calling for the emergence of capital markets. In the early 1990s, the Shanghai and Shenzhen Stock Exchanges were established. Accompanying this development, a number of laws, rules and regulations have been formulated. However, the Chinese market still suffers from suboptimal market mechanisms and low market efficiency. ${ }^{2}$ One of the major problems is the existence of non-tradable shares, a legacy from the corporatization of SOEs, in which the transfer of state-owned shares was deemed unnecessary. In 2005 , to address the problems caused by non-tradable shares, a reform was introduced to make these shares tradable.

This article argues that the Chinese reformers were extremely concerned about the incompatibility of market economy and socialism, apart from their belief that a modern corporate regime with the separation of ownership and management may be the cure to the inefficiency of SOEs. In every reform move, they have arguably taken a "one big leap forward but one step backward" approach. The corporatization of SOEs and establishment of stock exchanges were accompanied by a split share structure. Later, the split share structure reform was accompanied by the clear reluctance of the state to actually sell the shares. Apart from this, the rise of dispersed shareholding in China is now a possibility, rather than legally impossible. In the relationship between investor protection and stock market development, the "law matters" thesis

\footnotetext{
* DPhil candidate, Faculty of Law, University of Oxford. This paper was presented in the Oxford Corporate and Financial Law Reading Group on January 29, 2009, in "Regulating a World in Crisis", Osgoode Hall Law School, May 1-2, 2009, in Third International Graduate Legal Research Conference, King's College London, July 2-3, 2009 and "China and the Changing Landscape of the World Economy", Chinese Economic Association, July 23-24, 2009. I am grateful for all the comments and criticisms received. A shorter version of this article will appear in 30 (11) The Company Law. 341 (2009).

${ }^{1}$ Speech made by Deng Xiaoping on his Southern Excursion in 1992. See China Securities Regulatory Commission (CSRC), China Capital Markets Development Report, 161 (2008).

${ }^{2}$ Id. at 250 .
} 
is that investors will feel more comfortable in a protective jurisdiction and they are more willing to surrender funds in exchange for securities. ${ }^{3}$ The scope of capital markets will be expanded to develop a widely dispersed pattern of share ownership.

This article is structured as follows. The next part examines the ideological dilemma faced by the Chinese leaders in transforming the planned economy in China into a market economy. Part III is a review of the corporatization campaign and asks what problems it has caused. Part IV is about the non-tradable share reform, its progress so far and the market reception. Part V asks if the rise of dispersed ownership would occur in China. Part VI concludes. In summary, this article intends to give an overview of the past, present and future of the ownership structure problem in China to readers.

\section{THE IDEOLOGICAL DILEMMA}

After decades of dominance of state-owned enterprises in the Chinese socialist economy, China has begun to experiment with a modern corporate regime. Gaige kaifang, the twin strategies of reform and opening-up the economy, have been gradual and low profile. As put by the great Chinese leader, Deng Xiaoping, it is a pragmatic process of "crossing the river by feeling each stone". ${ }^{4}$ The Central Government aims to transform the planned economy into a market economy. At the same time, its main concerns are that the reforms may lead to the loss of state assets, result in massive unemployment and cause social unrest. ${ }^{5}$ There is a trade-off between retaining the ownership of SOEs and letting them go into private hands. For the former, the problem is the difficulty in reality for the state to monitor the management of every SOE. This somewhat contradicts with the state's desire to improve SOEs' efficiency. ${ }^{6}$ For the latter, mass layoffs may be the result. ${ }^{7}$ This is a situation where the Central Government is unwilling to see as it is very keen on maintaining social stability and keeping unemployment to a minimum.

\footnotetext{
${ }^{3}$ Rafael La Porta et al, Legal Determinants of External Finance, 52 J. Fin. 1131 (1997); Rafael La Porta et al, Law and Finance, 106 J. Pol. Econ. 1113 (1998); Rafael La Porta et al, Investor Protection and Corporate Governance, 58 J. Fin. Econ. 3 (2000). Bernard Black, The Legal and Institutional Preconditions for Strong Securities Markets, 48 UCLA L. Rev. 781 (2001).

4 The Second Long March, Economist, December 11, 2008, http://www.economist.com/PrinterFriendly.cfm?story_id=12758848 (last visited December 15, 2008).

${ }^{5}$ Ross Garnaut et al, China's Ownership Transformation: Process, Outcomes, Prospects, 32 (2005).

${ }^{6}$ In 1985, 9.6 per cent of all industrial SOEs declared losses, amounting to RMB 2.7 billion. In 1995, 44 per cent of them declared losses and the amount rose to RMB 40.9 billion. See Yang Chen, Ownership in China's Transitional Economy, 54 (2007).

${ }^{7}$ Robert Dodds, State Enterprise Reform in China: Managing the Transition to a Market Economy, 27 L. \& Pol'y in Int'l Bus. 695, 723 (1995). SOE employees had traditionally viewed job as the guaranteed welfare provided by the socialist state. The government had been reluctant to close unprofitable SOEs for fear of worker discontent.
} 
Since the beginning of the early 1980s, the proposal to reform in China has three broad phases: the state's withdrawal from operational decisions of SOEs, then from administrative oversight and ultimately from ownership. ${ }^{8}$ The relative share of the exclusively state-owned enterprises in the economy declined whilst hybrid structures co-owned by state entities and nonstate actors emerged. ${ }^{9}$ However, it appears that China is only somewhere in the second phase of transition. The difficulty for China to make a clear break with its socialist past and leap into capitalism largely comes from the Chinese leadership's stubborn rejection of privatization. ${ }^{10} \mathrm{Zhu}$ has noted that since the 1980s two main themes had been running throughout the reform agenda in China: one is to ensure the primacy of socialist ownership and the other is to restrict foreign ownership in state-owned enterprises. ${ }^{11}$ To bring the state enterprises further within the market economy but without privatizing their ownership structure, China created a comprehensive legal framework aimed at transforming state-run enterprises into state-owned ones. ${ }^{12}$ The goal was to separate the government's ownership of an enterprise from its management and administration.

Nonetheless, the introduced corporate structures based on western business models may not necessarily work well with pre-existing managerial and financial structures in the Chinese business environment, which has heavily been influenced by kin-ship network and state patronage. ${ }^{13}$ The reception or imitation of the form of western corporate institutions can be

\footnotetext{
${ }^{8}$ Stephen Green \& Guy Liu, Exit the Dragon: Privatization and State Control in China, 16 (2005). This is consistent to the transition path of other economies, particularly those former or current communist regimes. There would usually be three stages: the communist regime, the transition process and the post-transition regime. At the first stage, all enterprises are owned by the state and the management of the enterprises is appointed by the state organs. Gradually, all enterprises are transformed into corporations, but the corporate ownership and control is in the process of being defined. At the final stage, the corporate governance structure is well defined. There are due processes governed by law in dealing with issues like the appointment of management. See Masahiko Aoki, Controlling Insider Control: Issues of Corporate Governance in Transition Economies in Aoki and Kim eds., Corporate Governance in Transitional Economies: Insider Control and the Role of Banks, at 6 (1995).

${ }^{9}$ Statistically, the dominance of SOEs in the Chinese economy has been diminishing from accounting for 76 per cent of annual gross industry output in 1980 to only around 15 per cent in 2006, see China Statistical Yearbook, http:/www.stats.gov.cn/eNgliSH/statisticaldata/yearlydata (last visited January 3, 2009). However, in some public utility industries including water, electricity, thermal energy and fuel, the market share of SOEs still exceeded 50 per cent in order to protect public interests. See Sanlin Jin and Yuanyuan Wei, Extent of Government Ownership or Control of the Means of Production and Enterprises, in Li ed., Assessing the Extent of China's Marketization, at 239-242 (2006). Other than the emergence of collectively owned or privately owned companies in China, the fall of SOEs can also be explained by the increasing presence of foreign companies (including those from Hong Kong, Macau and Taiwan). Together, these companies accounted for around one-third of the total gross industry input in 2006.

${ }^{10}$ Andrew Wedeman, Corporate Capitalism in Socialist China, in Gomez ed., Chinese Enterprise, Transnationalism and Identity, at 73 (2003).

${ }^{11}$ Sanzhu Zhu, Securities Regulation in China, 169 (2000).

${ }^{12}$ Lan Cao, Chinese Privatization: Between Plan and Market, 63 L. \& Contemp. Probs. 13, 34 (2000)

${ }^{13}$ William Goetzmann and Elizabeth Koll, The History of Corporate Ownership in China, in Morck ed., A History of Corporate Governance around the World, at 150 (2005). Indeed, the sustainable development of western capitalist systems, according to Milhaupt and Pistor, should depend in part on the continuous development of new governance
} 
problematic without fully installing essential structures and features of the corporate system in accordance with the western interpretation. ${ }^{14}$ The focal point of reform may have mistakenly been put on form over substance. The basis of the socialist economic system of the People's Republic of China, which is the socialist public ownership of the means of production, arguably remains unchanged. ${ }^{15}$

\section{TO CORPORATIZE, BUT NOT PRIVATIZE}

The privatization campaign in China is clearly one with "Chinese characteristics". In contrast to those in Russia and Eastern Europe, there has not been any transfer of control from the state to the private hands. ${ }^{16}$ The Chinese government has introduced a special mechanism to prevent the loss of state control when companies go public. A distinct feature that separates China's stock market from those in other countries is the creation of state shares and legal person shares, which both carry significant constraints on tradability. These shares are generally state-owned or statecontrolled. On the other hand, tradable shares are composed of A, B and H shares (see Table 1). A typical public company has about one-third of its shares in each category of state, legal person and tradable shares. By holding two-thirds of most companies' shares, the state can ensure that it still has the power to direct and influence the activities of the companies (See Table 2). Although

structures to support capitalist enterprise. See Curtis Milhaupt and Katharina Pistor, Law and Capitalism, 27 (2008). In the view of Art and Gu, the corporate and securities laws in China closely followed Anglo-American patterns, but the laws were oriented to restructure state-owned enterprise instead of entrepreneurial, capitalist business in the western sense. See Robert Art \& Minkang Gu, China Incorporated: The First Corporation Law of the People's Republic of China, 20 Yale J. Int'1 L. 273, 307 (1995); Robert Art and Minkang Gu, Securitization of State Ownership: Chinese Securities Law, 18 Michigan J. Int'l L. 115, 124 (1996).

${ }^{14}$ Goetzmann and Koll argue that the transplantation of the western corporate system fell short on two counts. First, it did not sufficiently define a clear separation of ownership and control. Second, it did not facilitate the emergence of an active market for corporate control. See Goetzmann \& Koll, supra note 13. In fact, legal transplants have been a common problem of legal development around the world. The borrowing of law from other countries has been perceived as a way to address a problem or an institutional weakness in the domestic system. Unfortunately, this process is not that straightforward and easy. The theory of Milhaupt and Pistor is that, the nature of legal demand for the transplanted law and the process by which it is incorporated into the host country's institutional structure significantly affect whether and how the transplant will function. See Milhaupt \& Pistor, supra note 13. The difficulty experienced by Black and Kraakman in devising a corporate law framework for the Russian Federation is that corporate laws of developed economies depend upon highly evolved market, legal and governmental institutions and cultural norms that often do not exist in emerging economies. See Bernard Black \& Reinier Kraakman, A SelfEnforcing Model of Corporate Law, 109 Harvard L. Rev. 1911 (1996).

15 The Constitution of the People's Republic of China, art 6.

${ }^{16}$ See for example, Bernard Black et al, Russian Privatization and Corporate Governance: What Went Wrong?, 52 Stanford L. Rev. 1731 (2000) and Lan Cao, The Cat that Catches Mice: China's Challenge to the Dominant Privatization Model, 21 Brooklyn J. Int'1 L. 97 (1995). 
such classification of shares is a matter of reality, both the company law and the securities law of China make no mention of it. It was mentioned only once in the Standard Opinion for the Companies Limited by Shares. ${ }^{17}$ This first rule was the first systematic codification of the legal basis for the creation of a company in China and signaled the government's tentative affirmation of the shareholding experiment. ${ }^{18}$

${ }^{17}$ This rule was promulgated by the State Commission for Restructuring the Economic Systems on May 15, 1992, translated by LawInfoChina, http://www.lawinfochina.com. The classification of different types of shares was stated in art 24 of this rule.

${ }^{18}$ Fraser Howie \& Carl Walter, Privatizing China: The Stock Markets and Their Role in Corporate Reform, 72 (2003). 
Table 1 - China's Share Categories

\begin{tabular}{|c|c|c|}
\hline Tradable? & Category & Definition \\
\hline \multirow{3}{*}{$\begin{array}{l}\text { No } \\
\text { (Private block } \\
\text { transfer } \\
\text { possible) }\end{array}$} & State Shares & $\begin{array}{l}\text { Shares that are held by the department or institution } \\
\text { authorized by the State Council, or held by the } \\
\text { department or institution authorized by the local } \\
\text { people's government during the process in which the } \\
\text { state-owned enterprise are converted into a joint } \\
\text { stock company. The ultimate owner of state shares is } \\
\text { the State Council. }\end{array}$ \\
\hline & $\begin{array}{l}\text { Legal Person (LP) } \\
\text { Shares }\end{array}$ & $\begin{array}{l}\text { Shares that are sold to institutional shareholders (e.g. } \\
\text { securities companies and other SOEs) during the } \\
\text { corporatization process. }\end{array}$ \\
\hline & Employees Shares & Shares sold to the employees in the same process. \\
\hline \multirow{3}{*}{ Yes } & A Shares & $\begin{array}{l}\text { Shares issued by Chinese companies that are listed } \\
\text { and traded in the Shanghai or Shenzhen Stock } \\
\text { Exchange; these shares are sold to and held by } \\
\text { Chinese investors. }\end{array}$ \\
\hline & B Shares & $\begin{array}{l}\text { Shares issued by Chinese companies that are listed } \\
\text { and traded in the Shanghai or Shenzhen Stock } \\
\text { Exchange; these shares are sold to and held by } \\
\text { foreign investors; starting from } 2001 \text { Chinese } \\
\text { investors can also trade these shares. }\end{array}$ \\
\hline & H Shares & $\begin{array}{l}\text { Shares issued by selected Chinese companies listed } \\
\text { and traded in the Hong Kong Stock Exchange. }\end{array}$ \\
\hline
\end{tabular}

Source: Franklin Allen et al, China's Financial System: Past, Present, and Future (2007), available at http://ssrn.com/abstract=978485; Stephen Green, China's Stockmarket: A Guide to its Progress, Players and Prospects (2003) and the Standard Opinion for the Companies Limited by Shares. 
Table 2 - Distribution of Different Types of Shares in China's Listed Companies, 1997-2003

\begin{tabular}{|c|c|c|c|c|c|c|}
\hline Type & State & LP & Employee & A & B & H \\
\hline Range & $32-47 \%$ & $17-31 \%$ & $<2 \%$ & $23-28 \%$ & $<6 \%$ & $<6 \%$ \\
\hline
\end{tabular}

Source: Guy Liu and Pei Sun, China's Public Firms: How Much Privatization?, in Green and Liu eds., Exit the Dragon? Privatization and State Control in China, at 114 (2005).

The corporatization campaign in China has been a two-step process. It first restructured state-owned enterprises into shareholding companies and then they would be listed on a stock exchange. The establishment of two stock exchanges in China happened at around the same time. The Shanghai Stock Exchange (SHSE) was founded on 26 November 1990 and opened its first trading day on December 19, 1990. The Shenzhen Stock Exchange (SZSE) was founded in the same year on December 1 and formally opened for trading on July 3, 1991. One of the main objectives to establish the stock market is to strengthen the supervision over the managers of the SOEs through a market mechanism. Professional managers pursuing business instead of political objectives could be recruited to run the companies and they would be exposed to the discipline of the capital markets. ${ }^{19}$ On the other hand, investors could supervise the management through their rights to vote and rights to appoint. ${ }^{20}$ In addition, it provides an addition source of funding to finance the re-structured SOEs and the emergence of non-state-owned companies. ${ }^{21}$

With the particular aim of helping SOEs to raise funds, China has rapidly developed its stock market since 1991, with more than 1,500 companies listed by the end of 2008, most of them former SOEs. The general pattern of the development of the Chinese stock market from 1991 is given in the table below.

\footnotetext{
${ }^{19}$ Milhaupt and Pistor, supra note 13, at 139.

${ }^{20}$ The decision making power of non-state investors has been arguably ineffective due to the majority stakes owned by the state.

${ }^{21}$ The non-performing loan problem has severely disrupted the state-controlled banking system. See McKinsey Global Institute, Putting China's Capital to Work: The Value of Financial System Reform (2006), available at http://www.mckinsey.com/mgi/publications (last visited November 17, 2008), at 35. State ownership of banks reduced competition and lessened pressure on banks to operate on a commercial, profit-oriented basis. First, there is a lack of good internal credit-assessment capabilities in many banks. Most of the non-performing loans in the past were due to directed lending policies by the government to fund state-owned enterprises, regardless of their profitability. Second, these state-owned banks have a decentralized structure. Lending decisions are made at the local branch level which is susceptible to influence from local government to favor local SOEs. Their diffuse structure also makes it difficult for banks to collect and share useful information among their regions to make an informed lending decision.
} 
Table 3 - The Development of China's Capital Markets 1991-2008

\begin{tabular}{|c|c|c|c|}
\cline { 2 - 4 } \multicolumn{1}{c|}{} & $\begin{array}{c}\text { Number of Listed } \\
\text { Companies }\end{array}$ & $\begin{array}{c}\text { Capitalization } \\
\text { (RMB in Million) }\end{array}$ & $\begin{array}{c}\text { Turnover } \\
\text { (RMB in Million) }\end{array}$ \\
\hline 1991 & 14 & 11,019 & 4,366 \\
\hline 1992 & 52 & 105,000 & 92,177 \\
\hline 1993 & 183 & 352,934 & 375,571 \\
\hline 1994 & 291 & 367,585 & 840,775 \\
\hline 1995 & 323 & 349,791 & 415,580 \\
\hline 1996 & 540 & 943,981 & $2,128,478$ \\
\hline 1997 & 764 & $1,708,630$ & $3,063,650$ \\
\hline 1998 & 851 & $1,950,565$ & $2,354,400$ \\
\hline 1999 & 949 & $2,647,117$ & $3,131,960$ \\
\hline 2000 & 1,088 & $4,809,100$ & $6,082,700$ \\
\hline 2001 & 1,160 & $4,352,200$ & $3,830,500$ \\
\hline 2002 & 1,224 & $3,832,900$ & $2,799,000$ \\
\hline 2003 & 1,287 & $4,245,800$ & $3,211,500$ \\
\hline 2004 & 1,377 & $3,705,600$ & $4,233,400$ \\
\hline 2005 & 1,381 & $3,243,028$ & $3,166,500$ \\
\hline 2006 & 1,434 & $8,940,390$ & $9,046,889$ \\
\hline 2007 & 1,550 & $32,714,089$ & $46,055,622$ \\
\hline 2008 & 1,625 & $12,136,644$ & $25,025,000$ \\
\hline
\end{tabular}

Sources: National Bureau of Statistics of China and China Securities Regulatory Commission

The principal function of any market is to price goods or services. The specific market condition that regulators and exchanges attempt to create is called the transparency. With a sufficient degree of transparency, investors have a level playing field on which to make their informed investment decisions. Regrettably, to Chinese companies and investors, the markets do not play this function, for the simple reason that the different classes of stock trade in different and functionally independent markets. ${ }^{22}$ An example will be the sale of Midea's legal person shares by its state-backed largest shareholder to a domestic institution at a heavily discounted

\footnotetext{
${ }^{22}$ Howie and Walter, supra note 18 , at 177.
} 
price. ${ }^{23}$ More importantly, many studies report that company performance is negatively related to the level of state ownership. ${ }^{24}$

\section{A. The Corporate Governance Problems in China}

Corporatization or sometimes under the term securitization refers to the legal and financial restructuring of state-owned enterprises through their conversion into joint-stock companies. This has caused many socio-economic and legal debates in China because such reform might change the nature of socialist public ownership. These debates involved a wide range of issues, from the fundamental principles of socialism and the efficiency of alternative economic and business forms to shareholders' rights. ${ }^{25}$ In the light of corporate governance, it was hoped that corporatization would achieve three goals: ${ }^{26}$

(1) change the ownership structure of the SOEs that features both state and non-state institutional shareholders in addition to small individual shareholders;

(2) separate the state from business operation for enterprises to achieve full autonomy;

(3) improve managerial incentives by installing shareholders with incentives and abilities to monitor the managers.

One of the major difficulties is to establish a clear mechanism of company control and management. An option is to leave decision making authority to boards of directors, which should be profit-oriented and free from direct intervention by state administrative organs. ${ }^{27}$

\footnotetext{
${ }^{23}$ Midea (SZSE: 000527) is a Chinese electronics manufacturer located in Shunde, Guangdong. In this transaction, a company called Meituo, acquired the shares in two blocks priced at RMB 2.95 and RMB 3 per share. Meanwhile, the net asset value of each share was RMB 4.07 and the listed A share price around RMB 13, see id., at 185.

${ }^{24}$ See for example, Daqing Qi et al, Shareholding Structure and Corporate Performance of Partially Privatized Firms: Evidence from Listed Chinese Companies, 8 Pacific Basin Fin. J. 587(2000) and Qian Sun et al, How does Government Ownership affect Firm Performance: Evidence from China's Privatization Experience, 29 J. Bus. Fin. \& Acct. 1 (2002).

${ }^{25}$ Jianfu Chen, Securitization of State-owned Enterprises and the Ownership Controversy in the PRC, 15 Sydney L. Rev. 59, 60 (1993).

${ }^{26}$ Jean Chen, Corporatization of China's State-owned Enterprises and Corporate Governance, in Brown \& MacBean eds., Challenges for China's Development - An Enterprise Perspective, at 60 (2005). In November 1993, the Third Plenum of the Fourteenth Central Committee of the Chinese Communist Party passed the Decisions on Several Issues about Building Socialist Economic System. The concept of "modern corporate framework" was put forward, emphasizing the separation of ownership and management and encouraging the development of diverse ownership structures.

${ }^{27}$ Chen, supra note 25 , at 65 .
} 
In practice, a prominent characteristic of Chinese listed companies is an overwhelmingly high percentage of non-tradable shares, which represent around two-thirds of all the listed companies' combined equity. A significant portion of the non-tradable shares have been state shares. This demonstrates that these listed companies are essentially state-owned. ${ }^{28} \mathrm{~A}$ large number of corporatized SOEs remain dominated by a single state shareholder that exercises its control either through formal channels such as shareholder voting, or through traditional channels such as the appointment of key personnel. ${ }^{29}$ According to a report compiled by the Shanghai Stock Exchange, immoral and opportunistic behaviors have been widespread within listed companies. ${ }^{30}$ Sometimes, these behaviors can be explained by the historical relationship between listed companies and unlisted parent companies. ${ }^{31}$ The latter implicitly assume that listed companies will and should help a parent company if the need arises. Similarly, if the listed company comes under pressure, it may call on the parent company for help. This may not cause any problem from the angles of both entities because they ultimately are owned by the state. Unfortunately, minority shareholders are often put in a disadvantaged position.

In addition to the majority-minority conflict, the state as the majority shareholder plays an ineffective role in monitoring the behavior of managers because the state is a collective body. The owner in theory of a state-owned enterprise is the government or "people as a whole". However, the owner in practice is the government organization at either the central level or the local level. Their conduct is governed purely by political considerations or the private benefits of the government officials instead of shareholders' value. There has not been any "real" ownership. There is no body within the state with sufficient and appropriate incentives to perform any monitoring. Also, enforcement against the improper conduct of managers may be difficult. The state's dual role of being both a regulator and the blockholders of many listed firms is problematic. ${ }^{32}$ A senior company manager may even have a higher rank in the government than the official of the China Securities Regulatory Commission. Meanwhile, the holders of tradable shares are typically minority shareholders with limited power to affect management

\footnotetext{
${ }^{28}$ According to an empirically based study of China's top 100 listed companies, the basic feature of Chinese corporate governance is the dominance of the state as the major shareholder. The ownership of shares is usually controlled by the national government through the state-owned Assets Supervision and Administration Commission or through China's provincial governments. See Andrews Neil \& Roman Tomasic, Minority Shareholder Protection in China's Top 100 Listed Company, 9 Austl. J. Asian L. 88 (2007).

${ }^{29}$ Donald Clarke, Corporate Governance in China: An Overview, 14 China Econ. Rev. 494, 499 (2003)

${ }^{30}$ The behaviors include: 1 ) transferring and appropriating company's profit and assets through unfair related party transactions; 2) neglecting conflict of interest and engaging in self-dealing in pursuit of private gains; 3) cheating on profit level to meet public offering requirements; 4) manipulating IPO and secondary market prices; 5) trading on insider information; 6) engaging in deceiving public investors for private gains through outright misrepresentation; 7) developing connections by using companies' resources. See Shanghai Stock Exchange, Corporate Governance Report 2003: Executive Summary (2004), http://www.sse.com.cn (last visited June 22, 2007).

${ }^{31}$ Stoyan Tenev \& Chunlin Zhang, Corporate Governance and Enterprise Reform in China, 101 (2002).

${ }^{32}$ Jian Fu \& Roman Tomasic, Legal Regulation and Corporate Governance in China's Top 100 Listed Companies, 27 Company Law. 278 (2006).
} 
decisions. ${ }^{33}$ As rightly observed by $\mathrm{Xi}$, even to institutional investors, the concentrated ownership structure of Chinese listed companies is the barrier for them to exercise their voting power in a meaningful way under the basic "one share, one vote" system. ${ }^{34}$ As a result, the use of corporatization as a cure to the inefficiency of SOEs stemming from the unity of ownership and control is fundamentally flawed because the state has never been willing to relinquish the shareholding and control of many listed companies. The presence of non-tradable shares has been a design to safely secure their control over the economy.

\section{FROM NON-TRADABLE TO TRADABLE}

Recognizing that the corporatization programme has merely set out some formalities of the corporate form but has never addressed the essence of governance issues, the State Council issued the Several Opinions on Promoting the Reform and Opening-up and the Stable Development of Capital Market in 2004 as the basis of further reform. ${ }^{35}$ This document states that stable steps should be taken to solve the circulation problem of the non-tradable shares. Subsequently in 2005, the Guiding Opinions on Share-trading Reform of Listed Companies (the "Guiding Opinions" hereinafter) and the Measures for Administration of Split Share Structure Reform of Listed Companies (the "Measures" hereinafter) were promulgated outlining the principles and the procedures to address the non-tradable shares problem. ${ }^{36}$ The Guiding

\footnotetext{
${ }^{33}$ The number of stock accounts in China exceeded 100 million in May 2007 for the first time. According to a survey released in June 2007 by the central bank of China, more than 40 per cent of Chinese residents favoured stock and fund investment, for the first time taking the place of savings as Chinese people's favourite investment option. See Securities Become Residents' Top Investment Option, China Daily, June 21, 2007. Their lack of professional knowledge means their investments may be highly speculative in nature. See, for example, Chinese Put Stock in Lady Luck, Fin. Times, May 12, 2007.

${ }^{34}$ Chao Xi, Institutional Shareholder Activism in China: Law and Practice: Part 1, 17 Int'l Company and Com. L. Rev. 251, 254 (2006). However, there have been incidents that institutional shareholder activism may be effective. For example, in April 2007, the Hong Kong-listed arm of China National Offshore Oil Corporation (CNOOC) voted 52 per cent to 48 per cent to stop the Chinese oil company from continuing to deposit funds with its state-controlled parent. The practice is widespread among many Hong Kong listed subsidiaries of state-controlled Chinese companies and has attracted growing criticism from investors concerning that the parent company could run off with the money. CNOOC lost the vote following a campaign led by Institutional Shareholder Services, the US based advisory group. See On Asia: Shareholder Activism Taking Root in Asia, Fin. Times, April 13, 2007.

${ }^{35}$ This was issued by the State Council on Jan 31, 2004, translated by LawInfoChina, http://www.lawinfochina.com. Apart from the non-tradable share problem, this document also addresses eight other issues such as perfecting the existing regulatory framework, improving the quality of listed companies, strengthening the coordination and cooperation of various departments, etc.

${ }^{36}$ The former was issued on Aug 23, 2005 jointly by the China Securities Regulatory Commission, State-owned Assets Supervision and Administration Commission, Ministry of Finance, People's Bank of China and the Ministry
} 
Opinions contemplate that the distinction of tradable and non-tradable shares has been a unique problem during the economic transition of China and this problem has distorted the pricing mechanism of the capital market. The non-tradable share reform is an attempt to perfect the market in order to facilitate a long term and also steady development. On the other hand, the Guiding Opinions stress that the reform aims at solving the technical problems regarding the future listing and trading of non-tradable shares. There is no implication that the state will consider selling the state shares to raise funds through the domestic capital market. This is consistent to what Chairman Shang of the CSRC said in June 2005, "Making all shares tradable does not mean selling out all shares". 37 The exact procedures of how the reform should be implemented were left to the CSRC. Any sale of the state shares would have to be approved by the State-owned Assets Supervision and Management Commission.

\section{A. Procedural Rules}

According to the Measures, the share-trading reform can be roughly divided into four stages: initiation, negotiation, approval and implementation.

\section{INITIATION}

The whole process is initiated by the holders of non-tradable shares. The motion of reform shall be, in principle, raised through a unanimous decision of all the holders of nontradable shares. If a consensus fails to be achieved, the motion can also be raised independently or jointly by the shareholders who hold two-thirds or more of the non-tradable shares. ${ }^{38}$ Afterwards, the board of directors will employ intermediaries, for example, investment banks and lawyers, to assist the company with drafting the reform proposal and to give opinions on compliance issues.

\section{NEGOTIATION}

The reform proposal must be adequately disclosed to and consulted with the holders of tradable shares. This can be done in various ways, for instance, through an investors'

of Commerce. The latter was issued on September 4, 2005 by the China Securities Regulatory Commission. The English versions of both rules are available from LawInfoChina, http://www.lawinfochina.com.

${ }^{37}$ China to Include H Shares in Stock Reform Plan, Fin. Times, June 27, 2005.

${ }^{38}$ The Measures, art 5. 
symposium, press conference and roadshow. ${ }^{39}$ Telephone hotline, fax number and email address should also be available to these shareholders if they would like to express their opinions. In the event that adjustments to the reform plan are necessary, the board of directors may adjust it. Otherwise, a shareholders' meeting will be held. Before the meeting, the board of directors is required to publicize the details of it on approved newspapers and magazines no fewer than two times. ${ }^{40}$

\section{APPROVAL}

The reform plan will be adopted at the relevant shareholders' meeting if two-thirds of all shareholders and at the same time two-thirds of all holders of tradable shares agree. ${ }^{41}$ The board of directors will then announce the implementation of the reform plan. Otherwise, the whole process stops here. The holders of non-tradable shares can re-initiate a new proposal after three months. The whole process will then start from the first stage again.

\section{IMPLEMENTATION}

The sale of the originally non-tradable shares of any company after the reform is subject to the following provisions: ${ }^{42}$

(1) Within 12 months as of the date of implementing the reform scheme, these shares cannot be traded;

(2) After expiration of the 12-month period, the shareholders of these shares holding 5 per cent or more of the total amount of shares of any listed company, can sell no more than 5 per cent of the total amount of shares of the company within 12 months and no more than 10 per cent within 24 months.

In the event that the implementation of the reform scheme causes the changes in the total shares held or controlled by shareholders, other relevant rules and regulations apply, for example, the Measures for the Administration of Disclosure of Shareholder Equity Changes of Listed Companies. ${ }^{43}$

\footnotetext{
${ }^{39}$ The Measures, art 10.

${ }^{40}$ The Measures, art 13.

41 The Measures, art 16.

42 The Measures, art 27.

43 The Measures, art 36. For example, the Measures for the Administration of Disclosure of Shareholder Equity Changes of Listed Companies, art 15 states that if an investor starts to hold or control more than 5 per cent of the shares issued by a listed company, this must be properly disclosed and a report on equity changes must be submitted within three working days after the date when the changes take place (English translation available from LawInfoChina, http://www.lawinfochina.com).
} 


\section{B. Progress}

The whole non-tradable share reform was carried out in phases. Prior to the announcement of a comprehensive procedural framework of how the reform should be implemented, the CSRC conducted a pilot program involving a first batch of four companies to transform non-tradable shares into tradable shares on April 29, 2005. These companies were Tsinghua Tongfang, Hebei Jinniu Energy Resources, Shanghai Zi Jiang Enterprise Group and Sany Heavy Industry. They were followed by a second batch involving 42 companies. The relatively smooth and successful completion of these trials led to the issuance of the Guiding Opinions and the Measures by the CSRC and other relevant bodies in September 2005, which officially began the full-scale implementation of the reform. There are two major technical difficulties faced by the reformers. The first one is the market response. There has been fear that a sudden surge in supply of shares would cause a short-term collapse of market. This was partly addressed by the state's explicit stance that the intention of the reform is not to sell all nontradable shares on the market. ${ }^{44}$ Another issue is how each reforming company would compensate the holders of tradable shares for potential loss that might be incurred in the reform process.

During a typical public offering process before the reform, an issuing company in China would make a promise to potential subscribers that the state shares, the legal person shares and the employee shares would remain unlisted and non-tradable in a prospectus. Hence, the subscribers are willing to pay a premium for the exclusive tradability of their shares. In order to convert non-tradable shares into tradable shares, the Chinese Contract Law requires the holder of non-tradable shares to reach agreement with the holders of tradable shares in order to change the status of shares and settle on appropriate compensation. ${ }^{45}$ The need to compensate the shareholders of tradable shares is also stated in the Measures. It states that the reform is a process to eliminate the systematic discrepancy of share transfer in the market through a consultation mechanism to balance the interests between the holders of non-tradable and tradable shares. ${ }^{46}$ Therefore, in principle, it is largely left to the reforming companies and their shareholders to decide what the appropriate compensation scheme may be. The scheme may take the form of free distribution of bonus shares, bonus shares plus cash, stock splits, options or pure cash payment. In the large majority of cases, the shareholders have been compensated by means of bonus shares. $^{47}$

Among the 46 companies in the first two pilot programs, only Tsinghua Tongfang failed to pass its reform proposal on the initial attempt. Subsequently, more and more listed companies

\footnotetext{
${ }^{44}$ For example, see Fin. Times, supra note 37 for the speech by Chairman Shang .

${ }^{45}$ Contract Law of the People's Republic of China, art 77.

46 The Measures, art 2.

47 Bernardo Bortolotti \& Andrea Beltratti, The Nontradable Share Reform in the Chinese Stock Market (2006) FEEM Working Paper No. 131.06., http://ssrn.com/abstract=944412 .
} 
started their reform process. In February 2006, companies which accounted for more than half of the market capitalization of the Chinese stock market were in the process of reform. ${ }^{48}$ By the end of 2007, 1,298 companies listed on the Shanghai and Shenzhen Stock Exchanges had either initiated or completed the reform. ${ }^{49}$ As of November 7 2008, only 31 out of more than 1,500 listed companies in China had not completed the reform. ${ }^{50}$

\section{Conversion Schemes of the First Pilot Program ${ }^{51}$}

\section{Tsinghua Tongfang - Shanghai Stock Exchange Stock Code: 600100}

Tsinghua Tongfang is a Chinese maker of personal computers and software applications. About 301.6 million shares, 52.48 per cent of outstanding shares, were non-tradable. An offer of 3.56 shares for every 10 held was made in exchange for making the non-tradable shares tradable. An extraordinary general meeting was held on June 10, 2005. Shareholders representing only 61.91 per cent of tradable shares approved the plan, falling short of the minimum approval requirement of two-thirds. The first reform proposal was rejected.

A new reform plan was initiated at the end of 2005. The origin offer was 3.66 shares for every 10 held. However, it was modified and increased to 3.8 shares for every 10 held on January 5, 2006. Furthermore, the largest holder of non-tradable shares, Tsinghua Holdings promised that they would not sell any of their shares within 36 months as of the date of implementing the reform scheme, which is substantially longer than the one year period required by the Measures. A shareholders' meeting was held on January 23, 2006. 93.6 per cent of the holders of tradable shares voted for the plan. The plan was finally approved. As of the end of 2008, 74.72 per cent of all outstanding shares of Tsinghua Tongfang can be traded as A-shares on the market.

Sany Heavy Industry - Shanghai Stock Exchange Stock Code: 600031

Sany Heavy Industry is a manufacturer of construction machinery. About 75 per cent of outstanding shares were non-tradable at the time of reform. An offer of 3.5 new shares and RMB 8 for each 10 held was made. In addition, the largest holder of non-tradable shares, Sany Holding Company Limited promised that they would not sell any of their shares within 24 months as of the date of implementing the reform scheme, which is longer than the one year period required by the Measures. An extraordinary general meeting was held on June 10, 2005. Shareholders holding 93.44 per cent of the tradable shares approved the reform plan. As of the end of 2008, all outstanding shares of Sany can be traded as A-shares on the market.

\footnotetext{
${ }^{48}$ Shenzhen Stock Exchange, Research Report: A Review of the Split Share Structure Reform (2006), available from http://www.szse.cn/main/research (in Chinese) (last visited December 5, 2008).

${ }^{49}$ CSRC, supra note 1 , at 208.

${ }^{50}$ Chinese Capital Market on a New Historical Starting Point, China Securities Daily, November 13, 2008 (in Chinese).

${ }^{51}$ Compiled by the author using the company announcements found on the Shanghai and Shenzhen Exchanges and various newspaper articles.
} 
Shanghai Zi Jiang Enterprise Group - Shanghai Stock Exchange Stock Code: 600210 Shanghai Zi Jiang is a Chinese state-controlled maker of packaging materials. About 58.47 per cent of shares were non-tradable. An offer of 3 new shares for every 10 held was made. Moreover, the holders of non-tradable shares made a promise that they would not sell more than 10 per cent of the total amount of shares of the company within 48 months, which is longer than the period required by the Measures. A shareholders' meeting was held on June 13, 2005. About 77 per cent of the shareholders of tradable shares in the Shanghai-based company voted for the plan. As of the end of 2008, 80.74 per cent of all outstanding shares of Zi Jiang can be traded as A-shares on the market.

Jinniu Energy Resources - Shenzhen Stock Exchange Stock Code: 000937

Jinniu Energy Resources is a coal producer. About 66.39 per cent of shares were non-tradable. An offer of 2.5 new shares for every 10 held was made. Moreover, the holders of non-tradable shares promised that they would not sell any of these shares within 24 months as of the date of implementing the reform scheme, which is longer than the one year period required by the Measures. Even if they are to sell the shares after this period, they made an additional promise that the asking price must be higher than RMB 8.71 per share. A shareholder meeting was held on June 17, 2005. Shareholders holding 81.07 per cent of the tradable shares voted in favor of the reform plan. As of the end of 2008, all outstanding shares of Jinniu can be traded as A-shares on the market.

\section{RECEPTION}

In a study involving 368 sample companies, Beltratti and Bortolotti discovered that the non-tradable share reform generated an increase of eight per cent in total shareholder wealth, possibly owing to changes in fundamentals such as better corporate governance and enhanced liquidity. ${ }^{52}$ Using a larger sample size containing 880 companies, Cai and colleagues revealed a result which is consistent with that of Beltratti and Bortolotti. ${ }^{53}$ Before taking the compensation to existing owners of tradable shares into account, the reform generated average abnormal returns of 4.3 per cent. After considering the effect of compensation, the returns rose to 37.3 per cent. The CSRC claimed that the split share structure reform had been successfully implemented and had been remarkable in solving the legacy structural problem in the market. Certainly, for the first time, the amount of tradable shares in China was more than that of non-tradable shares in 2008 (see Figure 1 below). Nonetheless, if one examines the share structure of each company closely, it is probably still too early for the CSRC to say that.

Figure 1 - Share Structure of the Chinese Stock Market, 1992 to 2008

\footnotetext{
${ }^{52}$ Bortolotti \& Beltratti, supra note 47.

53 Jinghan Cai et al, What will Privatization Bring: The Non-Tradable Share Issue Reform in China (2007), available from http://ssrn.com/abstract=981682.
} 


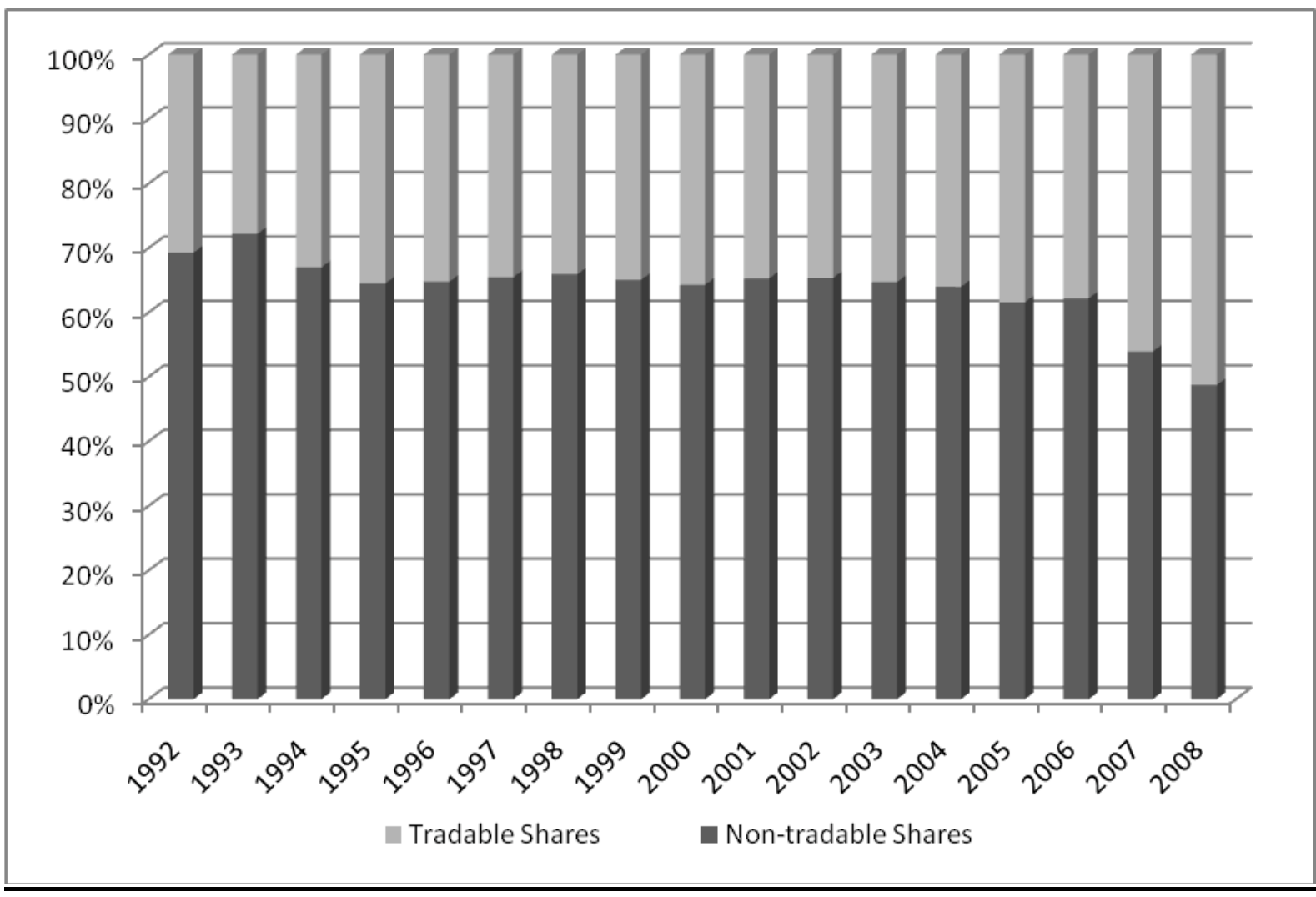

Source: CSRC

According to a survey of 1,596 listed companies in China in August 2008, only 19 of them had all their shares fully tradable. ${ }^{54}$ There were 627 companies still with 50 per cent or more of their shares non-tradable. It is understandable due to the mandatory selling restriction stipulated in the Measures and the voluntary restrictions agreed upon in many individual arrangements. The holders of the originally non-tradable shares are generally banned from selling their shares within 12 to 48 months starting from the date of implementing the reform. For the largest 30 companies, the overall percentage of tradable A-shares is only 28 per cent. ${ }^{55}$ For some of them, the percentage can be under 10 per cent. ${ }^{56}$ This illustrates that the state is particularly cautious

\footnotetext{
${ }^{54}$ See 30 Per Cent of Shares in the Largest 30 Companies are Tradable, China Securities Daily, August 28, 2008 (in Chinese).

${ }^{55}$ Id. Apart from the fact that Baogang Steel and China Construction Bank have their shares fully or almost fully tradable, the percentage of tradable shares of other 28 companies remained low.

${ }^{56}$ These companies include China National Petroleum Corporation (CNPC) (2.47 per cent), Haitong Securities (2.84 per cent), Bank of China (3.65 per cent), Industrial and Commercial Bank of China (ICBC) (5.96 per cent), China Life Insurance (7.2 per cent) and China CITIC Bank (8.64 per cent). See id. Except Haitong Securities, the other five are also listed in Hong Kong. This implies that the actual per centage of tradable shares of these companies is higher. For example, 11 per cent of all outstanding shares of CNPC are traded as H-shares in Hong Kong. The
} 
in unwinding the non-tradable shares of the large and usually more important state-owned enterprises. There may be three reasons. First, the state is unwilling to relinquish the control of these SOEs owing to some strategic reasons as most of them are large financial institutions and energy companies. ${ }^{57}$ Secondly, releasing a large amount of shares of these SOEs may affect the market sentiment easily. ${ }^{58}$ This somewhat contradicts with the goal of the state, which is to promote market stability. Thirdly, most of these SOEs are dual-listed in foreign markets like Hong Kong. A considerable proportion of shares of these SOEs have already been tradable as Hshares in Hong Kong. Also, how to compensate the foreign shareholders has been a complicated issue. $^{59}$

The owner of 2.3 per cent of the equity in Sany Heavy Industry, which was the first company to complete a reform, was able to sell the shares on June 19, 2006. By the end of 2006, a total of 12 billion shares could potentially come onto the market, with a value of over RMB 70 billion. $^{60}$ Indeed, only 10 per cent of the shares that have been unlocked since 2006 were actually sold to the market. ${ }^{61}$ As of 2008, there were to be USD 1,300 billion of shares becoming unlocked in the following two years. ${ }^{62} 2009$ is a particularly crucial year as there will be four times the number of unlocked non-tradable shares as in the previous year. (See Figure 2) State-owned companies

percentage of H-shares for China Life Insurance and ICBC is even close to one-fourth. To see the most updated ownership structure of these companies, visit the website of Shanghai Stock Exchange, http://www.sse.com.cn.

57 The preservation of government control may be desirable in the spheres of national defense and public services. See Andrei Baev, Is There a Niche for the State in Corporate Governance--Securitization of State-Owned Enterprises and New Forms of State Ownership, 18 Houston J. Int'1 L. 1, 3 (1995). The basic dilemma is that the state wants to maintain full or controlling ownership in companies in several major sectors and at the same time it wants these companies to be run along commercial lines in the service of wealth maximization. See Donald Clarke, Corporatization, not Privatization, 7 China Econ. Q. 27 (2003).

58 Stability is the foremost concern of the Chinese government. Even some pure commercial decisions can be undermined. In December 2008, the Financial Times reported that Bank of America cancelled a USD 3 billion sale of China Construction Bank stock at the eleventh hour following unspecified objections from the Chinese government. This was clearly a gesture of goodwill from Bank of America so as to safeguard future relations in China. See UBS China Deal Set to be Followed by Rivals, Fin. Times, December 31, 2008.

${ }^{59}$ Angang Steel Company Limited was the first company, which is dual-listed in China and overseas, to undergo the split share structure reform. 2.5 shares and 1.5 warrants were offered to the shareholders of tradable A-shares for every 10 shares they held. Nonetheless, no compensation was given to the holders of H-shares (Angang is listed on the Hong Kong Stock Exchange). According to a legal researcher from the Shenzhen Stock Exchange, first, it is because the Chinese and Hong Kong markets are separate and have different pricing mechanisms. After the reform, non-tradable shares are to be traded in the Chinese market only. Therefore, there should be minimum impact on the Hong Kong market. Second, these overseas listed companies have made no promise in the IPO prospectus that the non-tradable shares would remain unlisted and non-tradable after their listings in the foreign markets. See Yonghong Yao, Fifteen Legal Issues Related to the Split Share Structure Reform, available from http://article.chinalawinfo.com/article/user/article_display.asp?ArticleID=30562 (last visited March 3, 2009).

${ }^{60}$ China Braced for Unwinding of Shares, Fin. Times, June 18, 2006.

${ }^{61}$ Insight: Chinese Bubble won't Burst yet, Fin. Times, April 7, 2008.

${ }^{62} I d$. 
such as Bank of China, Industrial and Commercial Bank of China hold 80 per cent of these shares. ${ }^{63}$ As most of the shares that had been locked up were state-owned, the end of the restriction would provide an indication of whether the state intended to use the non-tradable share reform to reduce its corporate holdings. On October 16, 2007, the Shanghai Composite Index reached the record high of 6,093 points but it plunged to around 1,800 points as of the end of $2008 .{ }^{64}$ With a combination of the global credit crisis and the threat of billions of previously non-tradable shares becoming unlocked in the future, it is no wonder why the Chinese stock market is now at its low point. While securities analysts suggest that the problem of non-tradable shares had depressed the Chinese stock market for years, they also acknowledge that the split share structure reform has added a new risk factor when the lock-up period on selling shares begins to unwind. ${ }^{65}$

\section{Figure 2 - Percentage of Unlocked and To-be-unlocked Non-Tradable Shares}

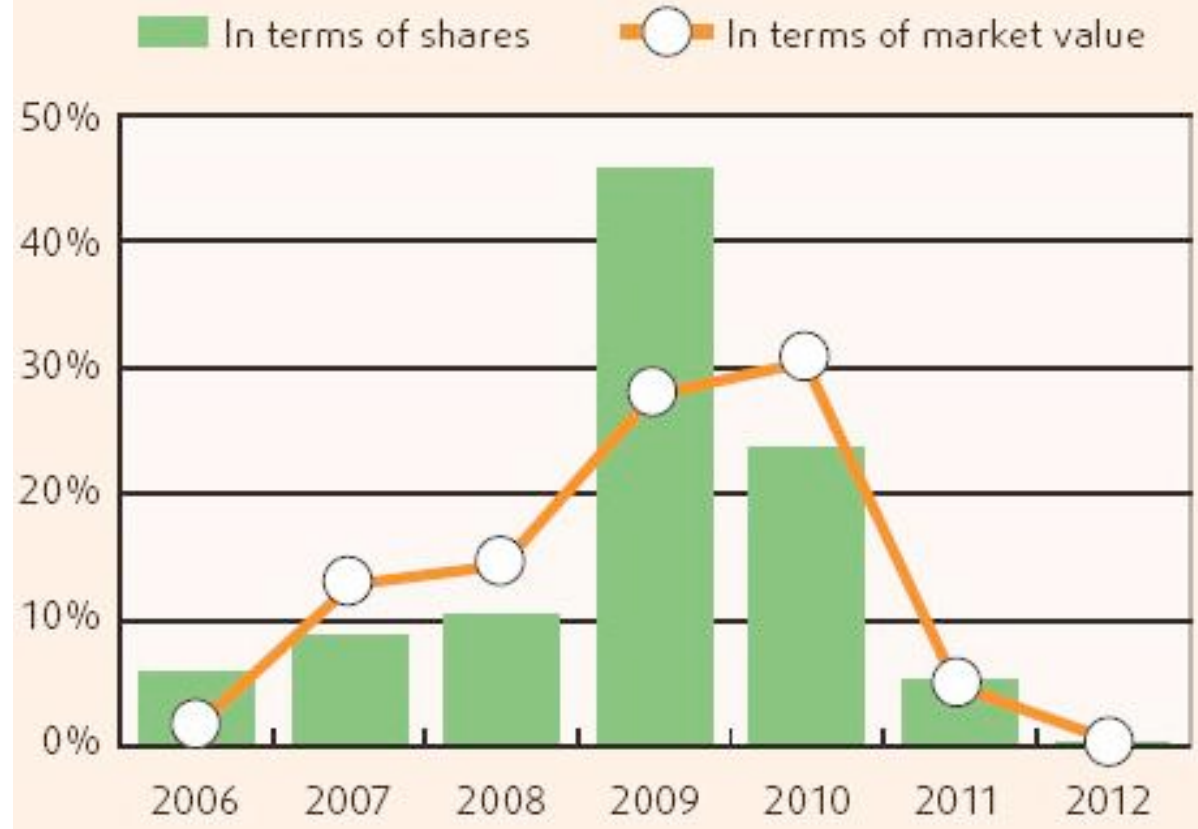

Source: Better Stock Performances Expected in Q2, China Daily, July 14, 2008

\footnotetext{
${ }^{63}$ A Strong Market may not Last Long, China Daily, February 23, 2009.

${ }^{64}$ For the historical figures of the indexes, visit Yahoo! Finance, http://finance.yahoo.com.

${ }^{65}$ See Beijing Asks Public Companies to Prepare for Share Sale, Fin. Times, June 1, 2005 and China Braced for Unwinding of Shares, Fin. Times, June 18, 2006.
} 
[Vol. 05 No. 09

\section{THE BERLE AND MEANS CORPORATION IN THE $21^{\text {ST }}$ CENTURY}

Adolf Berle and Gardiner Means in 1932 outlined a picture of separation of ownership and control in modern corporations. ${ }^{66}$ Their thesis was that the separation of ownership from management had resulted in shareholders being unable to exercise any form of effective control over boards of directors, who were theoretically appointed by them to represent their interests. The agency problem is a result of both the strategic behavior and the bounded rationality of managers. ${ }^{6}$

This appears to a side effect of the benefits offered by the modern corporate form. The privilege of incorporation were originally granted in order to enable a number of capitalists to embark upon risky adventures, whereas at the same time, without shouldering the burden of personal liability. ${ }^{68}$ Shareholders are able to diversify their investment risks by including the shares of companies from different sectors and different countries. This lowers the required returns by investors, thereby reducing the cost of capital of companies. Moreover, the possible specialization of professional management enhances the adaptability of the company to react to changes in the economic environment.

Shareholders were then starting to feel comfortable to relinquish many of the rights and powers traditionally associated with ownership by relying on the decision making by the boards of directors and the managers. Shareholders became functionless rentiers instead of the traditional view that they were owners. ${ }^{69}$ They took little or no direct interest in the companies, other than in the dividends paid and the share price. Indeed, a collective action problem causes most fragmented shareholders to rationally forgo involvement. ${ }^{70}$ Shareholder involvement is a function of the wealth, time and knowledge available to shareholders. Despite the potential gains to shareholders as a group, it is rational for each shareholder to do nothing because each would get only a fraction of the gain which accrues to the company and to all of the shareholders. The separation of ownership and management implies shortfalls of competence and responsibility. ${ }^{71}$

\footnotetext{
${ }^{66}$ Adolf Berle \& Gardiner Means, The Modern Corporation and Private Property (1991).

${ }^{67}$ David Campbell, The Role of Monitoring and Morality in Company Law: A Criticism of the Direction of Present Regulation, 7 Austl. J. Corporate L. 343, 349-351 (1997). Roe defined the resulting managerial agency costs as the sum of managers' overreaching (unjustifiably high salaries, self-dealing transactions, and so on) and their mismanagement. See Mark Roe, Corporate Law's Limits, 31 J. of Legal Stud. 233, 242 (2002).

${ }^{68}$ Christopher Stanley, Corporate Personality and Capitalist Relations: A Critical Analysis of the Artifice of Company Law, 19 Cambrian L. Rev. 98, 100 (1988).

${ }^{69}$ Paddy Ireland, Defending the Rentier: Corporate Theory and the Reprivatization of the Public Company, in Parkinson et al eds., The Political Economy of the Company (2000).

${ }^{70}$ Mark Roe, Strong Managers Weak Owners: The Political Roots of American Corporate Finance, 5 (1994).

${ }^{71}$ William Bratton, Berle and Means Reconsidered at the Century's Turn, 26 J. of Corporation L. 737, 740 (2001).
} 
Rentier owners are not generally well-equipped to protect themselves. This leads to a call for a wide range of legal and other interventions aiming at the elimination of deceit and swindling. ${ }^{72}$

In fact, dispersed ownership structure is a representative feature of Anglo-American companies only, but is rarely found elsewhere in the world. ${ }^{73}$ Coffee indicated that the twentieth century saw the polarization of corporate structure between two rival systems of corporate governance. ${ }^{74}$ They are the dispersed ownership system and the concentrated ownership system. The former is characterized by strong securities markets, rigorous disclosure standards and high market transparency. In contrast, the latter is characterized by controlling blockholders, weak securities markets, high private benefits of control, low disclosure and market transparency standards. To explain the emergence of the Berle and Means corporations, the "law matters" thesis is that investors will feel more comfortable in a protective jurisdiction and they are more willing to surrender funds in exchange for securities. ${ }^{75}$ Therefore, the scope of capital markets will be expanded to develop a widely dispersed pattern of share ownership. Conversely, the "law does not matter" story is that strong laws are only a response to the demand from an already well developed market, instead of the cause of it. ${ }^{76}$ In either case, the correlation between strong securities markets, dispersed ownership and strong legal standards seems real.

\section{A. In the AfTERmath of THE CREDIT CRISIS}

The collapse of Lehman Brothers, the bailout plans of various financial institutions and a few large car manufacturers have cast doubt on the sustainability of the Anglo-American style of market economy. ${ }^{77}$ In theory, managers should be encouraged to take risks because an investor

\footnotetext{
72 Paddy Ireland, Property and Contract in Contemporary Corporate Theory, 23 Legal Stud. 453 (2003).

${ }^{73}$ Rafael La Porta et al, Corporate Ownership around the World, 64 J. Fin. 471 (1999). This research presented statistical evidence which suggested that controlling shareholders, maybe the state but more often a family, were present in most large companies.

${ }^{74}$ John Coffee, The Rise of Dispersed Ownership: The Roles of Law and the State in the Separation of Ownership and Control, 111 Yale L. J. 1 (2001).

${ }^{75}$ La Porta et al, supra note 3.

${ }^{76}$ Coffee, supra note 74 and Brian Cheffins, Does Law Matter? The Separation of Ownership and Control in the United Kingdom, 30 J. Legal Stud. 459 (2001).

${ }^{77}$ At the end of 2006, Fortune recommended ten stocks for investors to buy in 2007. American International Group (AIG) was among one of them. See 10 Stocks to Buy Now, Fortune, December 2006, http://money.cnn.com/popups/2006/fortune/invguide_stocks/index.html (last visited December 5, 2008). At the same time in 2006, Fortune heavily blasted the practices of financial institutions in China. See Rolling the Dice on China's Bank, Fortune, December 14, 2006. The end of this story is, in 2008, AIG needed to be rescued by the US government. Its share price dropped from around USD 70 in 2007 to as low as USD 1.25 in 2008. The financial institutions in China were also hit by the credit crisis, but the degree was not as severe as seen in the west. Certainly, it is not fair to make a judgment based on isolated incidents. Indeed, the overall performance of the stock markets in the UK and the US in 2008 was better than many other countries. The Dow Jones and the FTSE 100 only declined
} 
can, in accordance with his preferences, hedge or stay unhedged or reverse any of the company's risk position. In practice, excessive risk-taking can lead to the collapse of companies. A classic example is the Barings case. Barings Bank was brought to its knees by Nick Leeson. Instead of overseeing the risk-free arbitrage business, he engaged in a far riskier business of foreign currency market speculation and lost 1.4 billion of the bank's money. ${ }^{78}$

A central weakness of large public corporation is the conflict between shareholders and managers. Most top executives will be eager to see the fruits of their efforts as soon as possible. Among S\&P 500 firms, average CEO compensation climbed from USD 3.7 million in 1993 to USD 9.1 million in 2003 (an increase of 146 per cent). ${ }^{79}$ Conceptually, companies offering stock options can align the interests between top management and the shareholders. In reality, in order to maximize their personal gain, they will try to boost the share price. Eventually, it becomes more difficult to generate the performance necessary to support the sky-high stock price. They may engage in risky investments leading to excessive risk taking problems. In an extreme situation, managers under incredible pressure may even turn to manipulation or fraud. ${ }^{80}$

Indeed, both market-based and bank-centered systems have their own advantages. There is a view that banks finance only well-established, safe borrowers whilst stock markets can finance risky, productive and innovative projects. ${ }^{81}$ From a historical perspective, the growth of public securities markets was driven by the enormous financing requirements of railways. In 1853, 70 per cent of the entire capital issued by the railway companies was listed on the London Stock Exchange. $^{82}$ The financial infrastructure, which had been created by the demands for capital from railway companies, was later utilized to serve the similar financial needs of the steel auto and telephone industries. ${ }^{83}$ In the US and the UK, the financial markets play an important role in allocating resources, while in the continental system most of the companies are financed through banks. ${ }^{84}$ The differences in institutions and markets across countries also have implications for

by around 30 per cent whilst the Shanghai Composite Index plummeted by 65.4 per cent. All these financial data can be found on Google Finance, http://finance.google.com.

${ }^{78}$ Mark Hirschey, Organization Structure and Corporate Governance: A Survey, in Hirschey et al eds., Corporate Governance and Finance, 68 (2003).

${ }^{79}$ Lucian Bebchuk \& Yaniv Grinstein, The Growth of Executive Pay (2005), Harvard Law and Economics Discussion Paper No. 510, available from http://ssrn.com/abstract=648682, at 3.

${ }^{80}$ Another classic example is the Enron case. Accounting practices that "push limits" and "at the edge of acceptable practice" were used. See the Permanent Subcommittee on Investigations of the Committee on Governmental Affairs United States Senate, The Role of the Board of Directors in Enron's Collapse (2002), available at http://news.findlaw.com/hdocs/docs/enron/senpsi70802rpt.pdf. (last visited December 10, 2008). Enron's collapse led to the demise of its auditor Arthur Anderson.

${ }^{81}$ Guglielmo Caporale et al, Stock Market Development and Economic Growth: the Causal Linkage, 29 J. Econ. Dev. 33, 36 (2004).

${ }^{82}$ Youssef Cassis, Capitals of Capital, 56 (2006).

${ }^{83}$ Coffee, supra note 74 , at 26.

${ }^{84}$ As of today, banks still intermediate nearly 75 per cent of the capital in China, a significantly higher proportion than in other Asian countries (43 per cent in India, 35 per cent in Japan and 33 per cent in South Korea) and the 
corporate governance. In the market-based system, the equity markets provide a market for corporate control. Monitoring by the banks performs the same oversight in a bank-centered system.

The transition from concentrated to dispersed ownership in China may be hindered by path dependencies. ${ }^{85}$ The legal rules which made the majority of shares non-tradable may have gone. However, there are sufficiently strong incentives for the state to retain their lock on control in order to extract large private benefits of control. The Chinese government wants to maintain the primacy of socialist ownership. Moreover, the types of legal institutions that can facilitate the rise of dispersed share ownership are still under the process of development. Also, the AngloAmerican system may have lost its luster after the credit crisis. The potential gain for switching to a market-oriented system may have diminished. In fact, $\mathrm{Xu}$ and Wang conducted an empirical study which revealed the correlation between the ratio of state, legal person and tradable shares in China in relation to company performance. ${ }^{86}$ Surprisingly, they found out that having a higher ratio of tradable shares would not help.

\section{CONCLUSION}

The basis of the socialist economic system of the People's Republic of China is the socialist public ownership of the means of production. It appears that even if the shares owned by the state can now be traded on the market, these shares will still be tightly hold by the state for an indefinite period. Indeed, only 10 per cent of these shares have actually gone to the hands of private investors so far. Empirical evidence showed that the non-tradable share reform allowed shareholders to profit immediately because of the compensation offered. On the other hand, in the short term, the threat of unlocked non-tradable shares has depressed the market. However, in the long term, the reform should be beneficial to the market as maintaining a healthy circulation of shares should in theory promote market stability. On the company dimension, it is still hard to say whether the reform can improve corporate governance. Company ownership is still largely in the hands of government. Minority shareholders face high risks of expropriation when majority-minority conflicts exist. Meanwhile, principal-agent conflicts exist as well because the state appoints the management but is unable to monitor their behavior on an

United States (only 19 per cent). See McKinsey Global Institute, Mapping Global Capital Markets Fourth Annual Report (2008), available from http://www.mckinsey.com/mgi/publications (last visited November 11, 2008), at 19.

${ }^{85}$ Lucian Bebchuk and Mark Roe, A Theory of Path Dependence in Corporate Ownership and Governance, 52 Stanford L. Rev. 127 (1999).

${ }^{86}$ Xiaonian Xu and Yan Wang, Ownership Structure and Corporate Governance in Chinese Stock Companies, 10 China Econ. Rev. 75 (1999). 
ongoing basis. It appears that the reform is merely a technical change and unfortunately has failed to achieve anything in substance so far.

The political force is one determining factor as to whether the rise of dispersed shareholding will occur in China. Another factor is the readiness of legal institutions. Separation of ownership from control may be a cure for the ills of state-owned enterprises. ${ }^{87}$ There is a side effect caused by this cure. The mechanisms to regulate the opportunistic behavior of managers become a new area of concern. The increasing number of cases of both public and private enforcement of corporate and financial laws in recent years reflects an encouraging start. ${ }^{88}$ Furthermore, the stock exchanges in China have made good use of reputational sanctions as the mechanism of market regulation. ${ }^{89}$ The development of both legal and non-legal institutions is clearly paving the way for Chinese companies to accommodate a more dispersed ownership structure, but not necessarily be the one in the US and the UK. If the "law matters" thesis is true, the rise of dispersed share ownership in China may be a possibility. However, in the aftermath of the credit crisis, will China be committed to moving along the Anglo-American line?

\footnotetext{
${ }^{87}$ Clarke, supra note 29, at 497.

${ }^{88}$ See Katharina Pistor \& Chenggang Xu, Governing Stock Markets in Transition Economies: Lessons from China, 7 Am. L. \& Econ. Rev. 184 (2005) and Chao Xi, Case Note: Private Enforcement of Securities Law in China: Daqing Lianyi Co v ZHONG Weida and Others (2004), 1 J. Comp. L. 492 (2006).

${ }^{89}$ See Benjamin Liebman \& Curtis Milhaupt, Reputational Sanctions in China's Securities Market, 108 Columbia L. Rev. 929 (2008).
} 